\title{
Different Forms of Vanadate on Sugar Transport in Insulin Target and Nontarget Cells
}

\author{
Ralph J. Germinario, ${ }^{1,3 *}$ Susan P. Colby-Germinario, ${ }^{1}$ Barry I. Posner, ${ }^{1,3}$ and K. Nahm ${ }^{2}$ \\ ${ }^{1}$ Lady Davis Institute for Medical Research, SMBD-Jewish General Hospital, Montreal, Quebec, Canada \\ ${ }^{2}$ Department of Biology, Concordia University, Montreal, Quebec, Canada \\ ${ }^{3}$ Department of Medicine, McGill University, Montreal, Quebec, Canada
}

\begin{abstract}
The effects of several vanadates (ie, orthovanadate, pervanadate, and two stable peroxovanadium compounds) on basal and insulinstimulated 2-DG transport in insulin target and nontarget cell lines are reported, herein. In nontarget cells, exposure to vanadates $\left(5 \times 10^{-6}\right.$ to $\left.10^{-4} \mathrm{~mol} / \mathrm{L}\right)$ resulted in 2-DG transport stimulatory responses similar to those observed in 2-DG transport post exposure to $667 \mathrm{nmol} / \mathrm{L}$ insulin alone, or insulin in combination with vanadates. In 3T3-L1 adipocytes and L6 myotubes, exposure to a vanadate compound or $67 \mathrm{nmol} / \mathrm{L}$ insulin, stimulated 2-DG transport dramatically. Again, this effect on stimulated transport was similar to 2-DG transport post-treatment with the effective vanadates in combination with insulin. While pervanadate or stable peroxovanadates stimulated 2-DG transport at $10^{-5}$ to $10^{-6} \mathrm{~mol} / \mathrm{L}$, orthovanadate up to $10^{-4} \mathrm{~mol} / \mathrm{L}$ was not effective in stimulating $2-D G$ transport in any of the cell lines tested. The data indicate that the various peroxovanadates are clearly superior insulin mimetics while a more limited insulin mimesis is observed with orthovanadate over a wide variety of cell types.
\end{abstract}

\section{INTRODUCTION}

Vanadium is an essential trace element for higher animals $[1,2]$, whose specific physiological role has not been elucidated. Vanadate, a phosphate analogue, has been shown to be an insulin mimetic for a number of in vivo and in vitro insulin target tissue responses $[3,4,5,6,7,8]$. Apparently, its ability to inhibit tyrosine phosphatases $[9,10,11]$ results in increased protein phosphorylation leading to insulin-like effects $[12,13]$. Early studies employing vanadate demonstrated the insulin-like effects which translated into amelioration of blood glucose levels in streptozotocin-treated diabetic rats $[7,14,15]$. This has led to a dramatic increase in studies on vanadium salts as potential treatments for diabetes. A number of additional studies using vanadium compounds led to the development of a class of compounds called peroxovanadates. Early developments using $\mathrm{H}_{2} \mathrm{O}_{2}$ plus vanadate resulted in insulin mimetics of short term stability [16]. These compounds were considerably more active than vanadate. This was followed by the synthesis of stable peroxovanadium compounds which were potent phosphotyrosine phosphatase inhibitors and powerful insulin mimetics [17].

In this study, we have evaluated the effects of different vanadates (eg, orthovanadate, peroxovanadate, and two stable peroxovanadium compounds), at various concentrations, (ie, $10^{-4}$ to $10^{-8} \mathrm{~mol} / \mathrm{L}$ ) on basal and insulin-stimulated glucose transport. Further, these studies were performed on a number of cell cultures including connective tissue derived human fibroblasts, L6 myoblasts, L6 myotubes, 3T3-L1 fibroblasts, and 3T3-L1 adipocytes, to further characterize the insulin mimesis of the stable peroxovanadates in these cell cultures.

\section{MATERIALS AND METHODS}

\section{Cell culture}

Human Fibroblasts. The human fibroblast cell strains were grown in $1 \mathrm{X}$ penicillin/streptomycin antibiotic solution in modified Eagle's medium (MEM) supplemented with $1 \mathrm{mmol} / \mathrm{L}$ pyruvate and $10 \%(\mathrm{vol} / \mathrm{vol})$ fetal bovine serum (FBS).

The cells were grown in an atmosphere of $5 \% \mathrm{CO}_{2} / 95 \%$ air and were harvested from appropriate culture vessels after incubation for 5 minutes with $0.02 \%$ (wt $/ \mathrm{vol}$ ) EDTA and 1-2 minutes with $0.06 \%$ (wt/vol) trypsin (Difco Laboratories, Mich, USA). In all experiments, the cell strains were employed at passages never exceeding 20 passages.

L6 myoblasts. Myoblasts were grown in Dulbeccos minimum essential medium (DMEM) containing 10\% (vol/vol) FBS. At approximately $75 \%$ confluence, before any myotube differentiation was observed, myoblast studies were performed. For differentiation studies, the 10\% FBS-DMEM was removed and replaced by an equal volume of fusion medium $(\alpha$-MEM containing 2\% FBS (vol/vol)) [18]. All experiments were done $4-5$ days later when more than $85 \%$ of the cells were differentiated as assessed visually through morphology changes (ie, myotube formation). Both 10\% FBS-DMEM and $2 \%$ FBS $\alpha$-MEM were supplemented with a 100X penicillin/streptomycin antibiotic solution. L6 cells were subcultured every 3 days at about $75 \%$ confluence using a split ratio of 1:3. Cells were detached as described above for human fibroblasts. L6 cells were not used at greater than 14 passages. 3T3-L1 fibroblasts (pre-adipocytes). Cells were cultured routinely in DMEM with $10 \% \mathrm{FBS}$ ( $\mathrm{vol} / \mathrm{vol})$. Cells were 
plated and grown to confluence prior to induction of adipocyte differentiation. In transport studies, 3T3-L1 fibroblasts were used at confluence before induction. Induction of adipocyte differentiation employed the method of Frost and Lane [19]. At the time of the experiment, greater than $85 \%$ of the cells expressed the adipocyte phenotype. This was confirmed visually by observing considerable accumulation of lipid droplets, and by demonstrating the expression of increased insulin binding and the GLUT4 insulin responsive transporter-that is by Western analysis.

Essentially, the activity of the various vanadates was elucidated in insulin target and nontarget cell cultures to determine if these cell types responded similarly. Comparative results would indicate if similar pathways were operative in both cell types.

\section{2-DG transport procedure}

For human fibroblasts, details of the experimental protocol can be found in [20]. Briefly, cells were plated at $10^{4}$ cells $/ \mathrm{cm}^{2}$ on plastic Petri dishes $(35 \mathrm{~mm}$ diameter, Falcon) and grown to confluence (usually 6-7 days). The cell monolayers were rinsed once in serum-free MEM, containing $1 \mu \mathrm{mol} / \mathrm{L}$ dexamethasone [21] for human fibroblasts or serum-free DMEM for other cell types (containing $1 \mathrm{mg} / \mathrm{ml}$ bovine serum albumin (BSA)) (0\% MEM; and 0\% DMEM, resp) and incubated 24 hours before exposure to experimental conditions. Glucose transport was assessed by measuring the uptake of 2-( $\left.{ }^{3} \mathrm{H}\right)$-deoxy-D-glucose (2-DG) in PBS (pH 7.4) containing $1 \mathrm{mmol} / \mathrm{L} 2-\mathrm{DG}$ (specific activity $5 \mathrm{mCi} / \mathrm{mmol}$ ) at $37^{\circ} \mathrm{C}$. Zero-time adsorption controls were subtracted. At the end of a specified time interval, the radioactive medium was removed and the monolayers were rinsed 4 times with $4^{\circ} \mathrm{C}$ PBS containing $5 \mu \mathrm{mol} / \mathrm{L}$ cytochalasin B. Then the monolayers were dissolved in $1 \mathrm{~N} \mathrm{NaOH}$, and aliquots were taken for liquid scintillation counting and protein determination [22].

For L6 cells, cells were grown to the appropriate stage of differentiation and serum deprived for 18 hours in $0 \%$ DMEM. The only other difference from the preceding protocol was that ${ }^{3} \mathrm{H}$ 2-DG was employed at a concentration of $0.05 \mathrm{mmol} / \mathrm{L}$ (specific activity $0.023 \mu \mathrm{Ci} / \mu \mathrm{mol}$ ). All other conditions were as above.

For 3T3-L1 fibroblasts, whether we measured 2-DG transport in fibroblasts or adipocytes, the conditions were as described above for L6 cells except that the serum deprivation time which was only 2 hours for the 3T3-L1 adipocytes.

For all cell types, 2-DG uptake was linear and ratelimiting under the conditions stated in [20, 23, 24, 25].

\section{Cell fractionation and membrane isolation}

3T3-L1 adipocytes from $100 \mathrm{~mm}$ diameter plastic Petri plates (Falcon) were treated as described and plasma membranes isolated [25]. In short, after homogenization with a Dounce homogenizer, a $1000 \mathrm{xg}$ spin to remove unbroken cells and nuclei was performed. This was followed by a 27000 xg spin yielding a crude plasma membrane pellet. A 3-4 fold increase in ouabain sensitive ATPase activity was observed in the crude membrane preparation versus the activity seen in the crude homogenate (data not shown).

\section{Western analysis procedure}

The whole cell monolayers or membrane fractions were suspended in $0.5 \mathrm{ml} \mathrm{PBS}$ with the proteinase inhibitor (phenylmethylsulfonyl fluoride) at a final concentration of $1 \mathrm{mmol} / \mathrm{L}$. Prior to electrophoresis, samples were solubilized in $2 \%$ sodium dodecyl sulfate (SDS) (Pierce Chemical Co), 10\% glycerol, $1 \mathrm{mmol} / \mathrm{L}$ EDTA, 0.002\% bromphenol blue, $100 \mathrm{mmol} / \mathrm{L}$ tris- $\mathrm{HCl}(\mathrm{pH}$ 6.8). Electrophoresis was performed as described previously in $[24,25,26]$. Proteins were blotted onto nitrocellulose paper $(0.2 \mu \mathrm{m}$, Schleicher and Schull, Ontario, Canada) that was blocked with $1 \%$ BSA ( 1 hour at $20^{\circ} \mathrm{C}$ ). This was followed by incubation overnight at $4^{\circ} \mathrm{C}$ with specific rabbit polyclonal antibody (ie, anti GLUT1, diluted 1:1000 in blocking buffer). This antibody was induced using a purified erythrocyte glucose transporter prepared as described in [27]. Subsequently, 125-I labeled protein A (ICN), at $1.2 \times$ $106 \mathrm{dpm} / 10 \mathrm{ml}$ in blocking buffer containing $0.1 \%$ Triton $\mathrm{X}-100$, was added for 1 hour at $20^{\circ} \mathrm{C}$ (dpm: disintegrations per minute). Autoradiography was performed using Kodak XAR film (Eastman Kodak, Rochester, NY, USA) exposed at $-85^{\circ} \mathrm{C}$ overnight. Quantitation was determined by cutting out the exposed spots and counting in an LKB gamma counter with an appropriate matching nonlabelled portion of the blot counted and subtracted for background detection.

\section{Preparation of vanadate and pervanadate solutions}

The vanadate was prepared as previously described [5]. Pervanadate was prepared by mixing $10^{-3} \mathrm{~mol} / \mathrm{L}$ orthovanadate with $\mathrm{H}_{2} \mathrm{O}_{2}$, for 15 minutes at $22^{\circ} \mathrm{C}$. This was followed by the addition of catalase, $200 \mu \mathrm{g} / \mathrm{ml}$, to remove residual $\mathrm{H}_{2} \mathrm{O}_{2}$. This procedure resulted in an oxidized form of vanadate, which remained stable for 2 hours [28]. Stable peroxovanadium compounds [bpV (phen) and bpV (pic)] were synthesized as previously described in [17]. These compounds have been designated pVA and pVI, respectively.

\section{Insulin binding}

The insulin binding procedure was as described previously [21]. Briefly, the cell monolayers were washed twice with $22^{\circ} \mathrm{C}$ Hanks HEPES buffer containing $0.2 \% \mathrm{BSA}, \mathrm{pH}$ 7.4. Then the monolayers were incubated with $1 \mathrm{ng}{ }^{125} \mathrm{I}-$ insulin alone (total binding) or in the presence of $40 \mu \mathrm{g}$ of nonlabeled insulin (nonspecific binding). After 2 hours at $22^{\circ} \mathrm{C}$, the monolayers were rinsed four times with cold Hanks HEPES buffer containing $0.2 \%$ BSA, solubilized with $1 \mathrm{~N}$ $\mathrm{NaOH}$ and counted in a LKB gamma counter.

\section{Materials}

2- $\left({ }^{3} \mathrm{H}\right)-\mathrm{DG},{ }^{125} \mathrm{I}$-protein A, and ${ }^{125} \mathrm{I}-\mathrm{NaI}$ were purchased from ICN Radiochemical Division (Calif, USA). 2-DG was purchased from Calbiochem (Calif); BSA from Nutritional 
Biochemicals (Ill, USA) and sodium orthovanadate and phenylmethylsulfonylfluoride from Sigma (Mo, USA).

\section{Statistics}

The level of significance chosen for any statistical analysis employed herein was $5 \%$.

\section{RESULTS}

\section{Effect of various vanadates on 2-DG transport in human fibroblasts}

In Figure 1a, short term exposure (ie, 60 minutes) of human fibroblasts (HF) to increasing concentrations of sodium orthovanadate resulted in increased 2-DG transport that appeared to peak at $10^{-5} \mathrm{~mol} / \mathrm{L}$. While the data indicated that $10^{-5} \mathrm{~mol} / \mathrm{L}$ orthovanadate was a maximally effective concentration, statistical analysis showed that no significant differences existed between the various groups analyzed (1-way ANOVA; $F=2.983, P>.05, n=4$, triplicate plates in each experiment). Significant stimulation of 2-DG transport by $667 \mathrm{nmol} / \mathrm{L}$ insulin was observed (control, $6.6 \pm 0.7$ vs insulin, $12 \pm 2 \mathrm{nmol} 2-\mathrm{DG} / \mathrm{mg}$ protein $/ 5$ minutes; $P<.5$, 1-way ANOVA) while no significant difference $(P>.05)$ was observed $+10^{-5} \mathrm{~mol} / \mathrm{L}$ orthovanadate. In another series of experiments, the effects of pervanadate (prepared as described in Materials and Methods) [17] on HF were investigated over a range of concentrations (Figure 1b). The data in Figure $1 \mathrm{~b}$ demonstrated significant increases in 2-DG transport at both $10^{-5} \mathrm{~mol} / \mathrm{L}$ ( $a>60 \%$ average increase over control) and $10^{-4} \mathrm{~mol} / \mathrm{L}$ concentrations (1-way ANOVA, $F=$ 13.1, $P<.05, n=3$, triplicate plates in each experiment at various concentrations). While insulin $(667 \mathrm{nmol} / \mathrm{L})$ or $10^{-5} \mathrm{~mol} / \mathrm{L}$ pervanadate both significantly stimulated $2-\mathrm{DG}$ transport, no differences were observed between $10^{-5} \mathrm{~mol} / \mathrm{L}$ pervanadate, or insulin alone or versus both factors in combination $\left(667 \mathrm{nmol} / \mathrm{L}\right.$ insulin vs $10^{-5} \mathrm{~mol} / \mathrm{L}$ pervanadate vs $667 \mathrm{nmol} / \mathrm{L}$ insulin $+10^{-5} \mathrm{~mol} / \mathrm{L}$ pervanadate; $21.4 \pm 0.5 \mathrm{vs}$ $23.7 \pm 0.5$ vs $24.1 \pm 0.2 \mathrm{nmol} 2-\mathrm{DG} / \mathrm{mg}$ protein $/ 5 \mathrm{~min} ; 1-$ way ANOVA, $P>.05)$. Also, stable peroxovanadates [17] were evaluated over a similar range of concentrations. Significant stimulation of 2-DG transport was seen at $10^{-5} \mathrm{~mol} / \mathrm{L}$ and $10^{-4} \mathrm{~mol} / \mathrm{L}$ pVA (Figure 1c) (1-way ANOVA, $F=157.9$, $P<.01, n=3$, triplicate plates in each experiment at all concentrations). The optimal concentration for $\mathrm{pVA}$ was $10^{-5} \mathrm{~mol} / \mathrm{L}$, expressing an average increase $\sim 400 \%$ increase over control (Figure 1c). For pVI, significant increases were seen from $10^{-6}$ to $10^{-4} \mathrm{~mol} / \mathrm{L}$ (maximal at $10^{-5} \mathrm{~mol} / \mathrm{L}$ ) concentrations, which yielded increases of $\sim 300 \%$ over control values (Figure 1d). Additionally, the stimulation in 2DG transport seen at $10^{-6} \mathrm{~mol} / \mathrm{L}$ pVI was not observed with any other vanadate compound in HF. In all experiments, 60 minutes exposure time were employed as no change in stimulated 2-DG transport was observed for exposure times up to 120 minutes (data not shown). For both pVA and pVI, insulin $(667 \mathrm{nmol} / \mathrm{L})$ versus either stable peroxovanadate versus a combination of either with insulin was not significantly different $(P>.05$; 1 -way ANOVA, data not shown).

\section{Effect of various vanadates on 2-DG transport in 3T3-L1 cells}

We next investigated the effect of different concentrations of the stable peroxovanadate, pVA on 2-DG transport in 3T3-L1 fibroblasts. The data in Figure 2a demonstrate that pVA can increase 2-DG transport in these cells at a concentration of $5 \times 10^{-6} \mathrm{~mol} / \mathrm{L}$ or greater. The average stimulation ratio of $\mathrm{pVA}$ treated/control transport was between 1.4 and 1.5 fold. This ratio agreed favorably with the insulin/control transport ratio (1.58 fold). The 2-DG transport in control versus insulin-treated (ie, $667 \mathrm{nmol} / \mathrm{L}$ insulin) 3T3-L1 fibroblasts was $0.77 \mathrm{nmol}$ $2-\mathrm{DG} / \mathrm{mg}$ protein $/ 5 \mathrm{~min}$ versus $1.2 \mathrm{nmol} 2-\mathrm{DG} / \mathrm{mg}$ protein/5 min, respectively ( $P<.05, n=9,1$-way ANOVA). The combination of insulin $+10^{-5} \mathrm{~mol} / \mathrm{L}$ pVA resulted in similar 2-DG transport values as seen with either treatment alone (eg, insulin vs insulin $+10^{-5} \mathrm{~mol} / \mathrm{L}$ pVA 2 -DG transport: $1.3 \pm 0.5$ vs $1.5 \pm 0.3 \mathrm{nmol} / \mathrm{mg}$ protein $/ 5 \mathrm{~min}$; 1 -way ANOVA). The peak effect of pVA was seen at $5 \times 10^{-6} \mathrm{~mol} / \mathrm{L}$ $(P<.05,1$-way ANOVA). In a different series of experiments (Figure 2b), employing pVI in 3T3-L1 fibroblasts, 2DG transport was increased at $10^{-5} \mathrm{~mol} / \mathrm{L}$ and $10^{-4} \mathrm{~mol} / \mathrm{L}$ pVI. The average increase seen in 2-DG transport induced by pVI was $125 \%$ to $143 \%$, respectively $(P<.05, n=7$, 1 -way ANOVA). Again, no differences were seen in the insulin $(67 \mathrm{nmol} / \mathrm{L})$ versus insulin $+\mathrm{pVI}\left(10^{-5} \mathrm{~mol} / \mathrm{L}\right)$ groups; $P>.05$ (data not shown).

Our next series of experiments ascertained the effects of pVA and pVI on 2-DG transport in 3T3-L1 adipocytes. 3T3 cells were induced as described in [19] and over a period of 10 days, we observed increases in the cellular content of GLUT1 ( $\sim 3$ fold) and GLUT4 ( 10 fold) (data not shown). Further, specific insulin binding was also increased over the period of induction (eg, $12 \pm 4.3 \mathrm{fmol}$ ${ }^{125} \mathrm{I}$-insulin/mg p vs $3.5 \pm 1.2 \mathrm{fmol}{ }^{125} \mathrm{I}$-insulin $/ \mathrm{mg}$ protein, in the 3T3-L1 adipocyte vs the 3T3-L1 fibroblast, resp) $(P<.05, n=6,2$-tailed test). In concert with these changes, insulin responsiveness increased as evidenced by the maximally effective insulin concentration for 2-DG transport stimulation in 3T3-L1 adipocytes being $\sim 67 \mathrm{nmol} / \mathrm{L}$ versus $667 \mathrm{nmol} / \mathrm{L}$ as seen in 3T3-L1 fibroblasts (data not shown). Additionally, a comparison of specific insulin stimulation of sugar transport at $67 \mathrm{nmol} / \mathrm{L}$ for 3T3-L1 adipocytes and $667 \mathrm{nmol} / \mathrm{L}$ for 3T3-L1 fibroblasts was significantly different (ie, a $400 \%-600 \%$ increase for the adipocytes at $67 \mathrm{nmol} / \mathrm{L}$ insulin vs a $130 \%$ increase for the fibroblasts at $667 \mathrm{nmol} / \mathrm{L}$ insulin $) ;(P<.05, n=6,2$-tailed test $)$ (data not shown). Having established the nature of changes in sugar transport and the sugar transporters in the 3T3 cells (as also demonstrated by a number of other laboratories), we examined the effect of stable peroxovanadates on 2-DG transport. The data in Figure 3a depicts the effect of different concentrations of pVA on 2-DG transport in 3T3L1 adipocytes after 10 days of induction of the adipocyte phenotype. It is apparent that the maximum effect of pVA is seen at $10^{-5} \mathrm{~mol} / \mathrm{L}$. The increase in 2-DG transport over control is, on average, nearly 4 -fold at $10^{-5} \mathrm{~mol} / \mathrm{L}$ and $10^{-4} \mathrm{~mol} / \mathrm{L}$ 


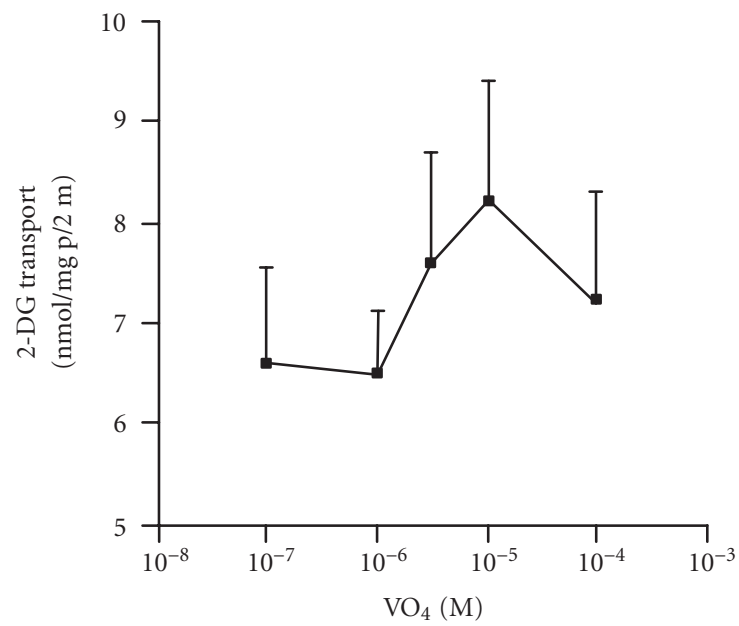

(a) Effect of $\mathrm{VO}_{4}$ on 2-DG transport in human fibroblasts.

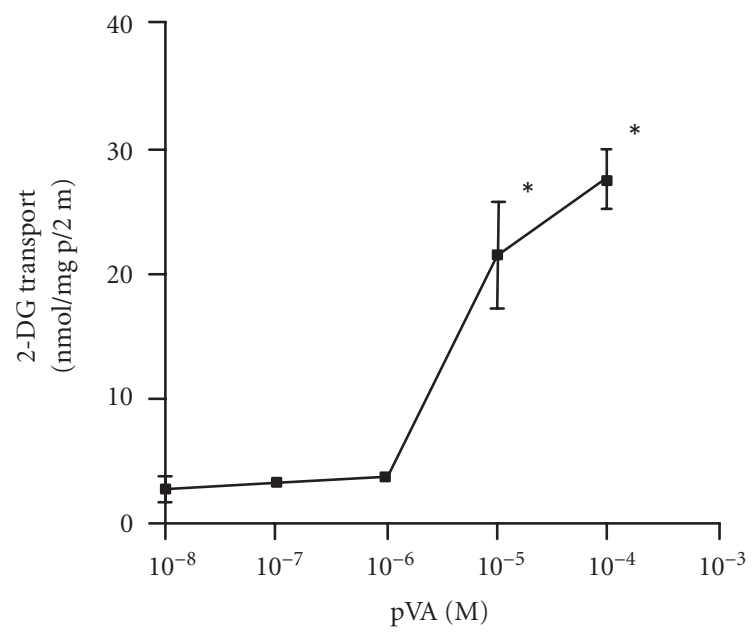

(c) Effect of pVA on 2-DG transport in human fibroblasts.

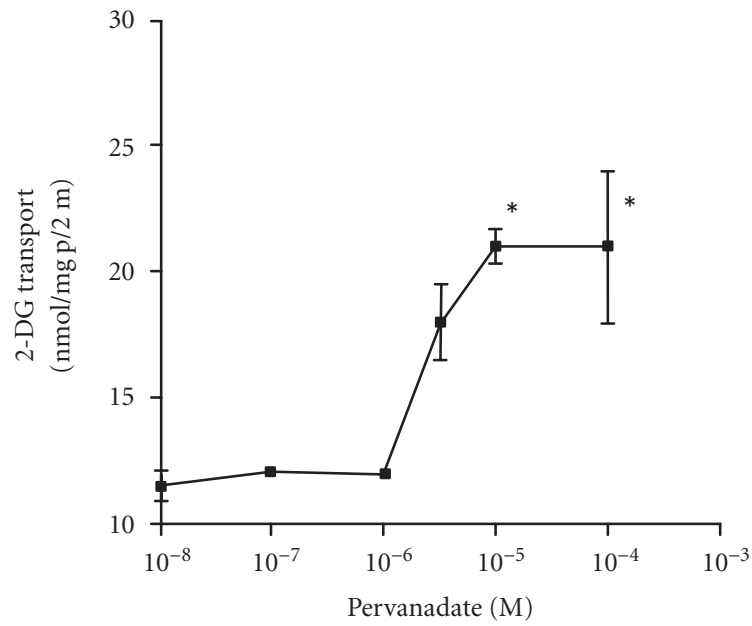

(b) Effect of increasing concentrations of pervanadate on 2DG transport in human fibroblasts.

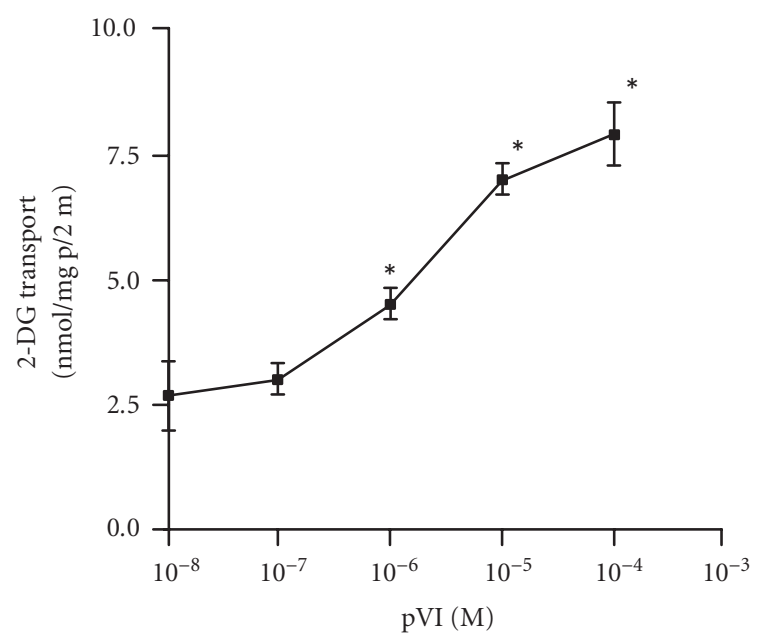

(d) Effect of pVI on 2-DG transport in human fibroblasts.

Figure 1. Effect of different vanadate compounds at several concentrations on basal and insulin-stimulated 2-DG transport in human fibroblasts. Panel (a) sodium orthovanadate; no significant differences were seen, $P>.05$, 1-way ANOVA, $F=2.983, n=4$ (triplicate plates in all experiments). Panel (b) pervanadate; $P<.05,1$-way ANOVA, $F=13.1, n=3$ (triplicate plate in all experiments). Panel (c) pVA; ${ }^{*} P<.05,1$-way ANOVA, $F=157.9, n=3$ (triplicate plates in all experiments). Panel (d) $\mathrm{pVI} ;{ }^{*} P<.05$, 1-way ANOVA, $F=38.2, n=3$ (triplicate plates in all experiments). All data \pm SE. The exposure time for all the vanadate compounds employed was 60 minutes. See Materials and Methods for additional experimental details.

pVA. In the same series of experiments, the average insulin (ie, $67 \mathrm{nmol} / \mathrm{L}$ ), or insulin $+10^{-5} \mathrm{~mol} / \mathrm{L} \mathrm{pVA}$ induced increase in 2-DG transport, was $\sim 4$-fold (data not shown). In another series of experiments, we employed pVI (Figure $3 \mathrm{~b}$ ) and the significantly effective concentrations of $\mathrm{pVI}$ were found to be $10^{-5} \mathrm{~mol} / \mathrm{L}$ ( $\sim 5$-fold increase) and $10^{-4} \mathrm{~mol} / \mathrm{L}$ ( 4-fold increase). Insulin at $67 \mathrm{nmol} / \mathrm{L}$ elicited an average 4.4 -fold increase in 2-DG transport. Next, we sought to demonstrate the effects of pVA on the translocation of glucose transporters to the cell plasma membrane. In Figure 4, it can be seen that exposure to $67 \mathrm{nmol} / \mathrm{L}$ insulin results in a significant translocation of the GLUT1 and GLUT4 transporters into a crude plasma membrane preparation. In the same experiments, in a parallel series of plates, the 3T3-L1 adipocytes were exposed to $10^{-5} \mathrm{~mol} / \mathrm{L} \mathrm{pVA}$ and the GLUT1 and GLUT4 content of plasma membranes were determined. Clearly, the pVA resulted in a significant translocation of these transporters in a pattern nearly identical to that observed with insulin $(P<.05, n=3$; 1-way ANOVA).

\section{Effect of various vanadates on 2-DG transport in L6 myoblasts and L6 myotubes}

The effect of orthovanadate pVA or pVI $\left(10^{-7}\right.$ to $10^{-4} \mathrm{~mol} / \mathrm{L}$ ) on L6 myoblasts was not significantly different 


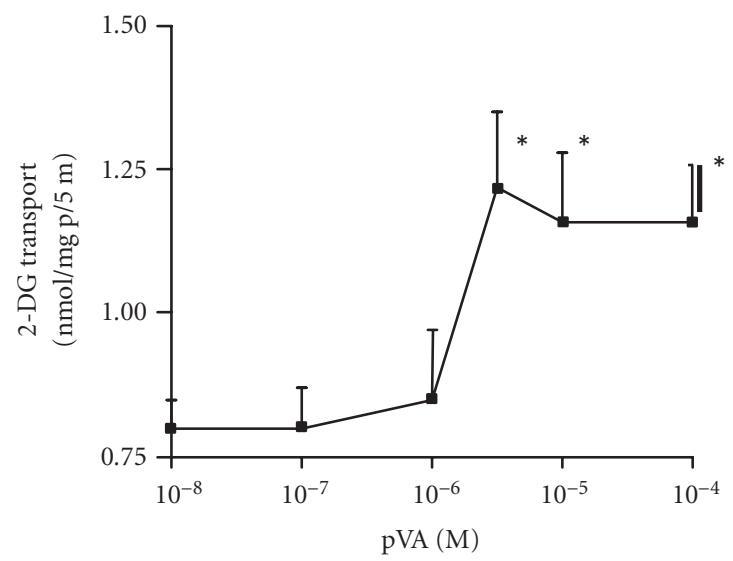

(a) Effect of increasing concentrations of pVA on 2-DG transport in 3T3-L1 fibroblasts.

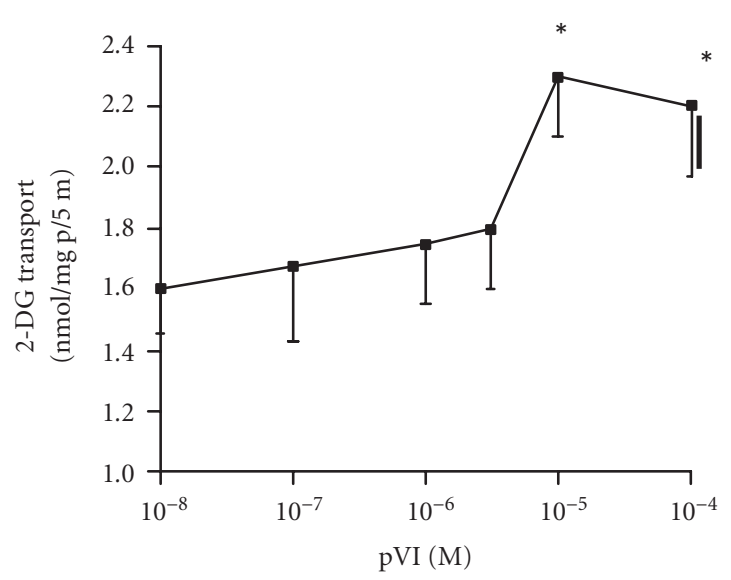

(b) Effect of increasing concentrations of pVI on 2-DG transport in 3T3-L1 fibroblasts.

FIGURE 2. Effect of different vanadate compounds at several concentrations on basal and insulin-stimulated 2-DG transport in 3T3-L1 fibroblasts. Panel (a) pVA; ${ }^{*} P<.05,1$-way ANOVA, $F=8.95, n=9$ (triplicate plates in all experiments). Panel (b) pVI; ${ }^{*} P<.05,1$-way ANOVA, $F=4.99, n=7$ (triplicate plates in all experiments). All data \pm SE. pVA or pVI exposure time was for 60 minutes. See Materials and Methods for additional experimental details.

from control 2-DG transport (Figure 5) $(P>.05, n=8$, 1 -way ANOVA). The myoblasts did respond to $10^{-5}$ and $10^{-4} \mathrm{~mol} / \mathrm{L} \mathrm{pVA}$ (Figure 5) exhibiting a modest increase (ie, $118 \%-127 \%$, resp) $(P<.05, n=6,1$-way ANOVA). Additionally, pVI exposure resulted in increased 2-DG transport at a concentration of $10^{-4} \mathrm{~mol} / \mathrm{L} \mathrm{pVI}(154 \%)(P<.05, n=6$, 1-way ANOVA) (Figure 5). The average insulin-stimulated (ie, $667 \mathrm{nmol} / \mathrm{L}$ Insulin) 2 -DG transport was $121 \% \pm 9 \%$. Further, we investigated the effects of these vanadates on L6 myotubes which exhibited greater than $80 \%$ myotube formation and increased expression of GLUT4 ([25], data not shown). Again as observed with L6 myoblasts, there was no significant 2-DG transport increases in response to

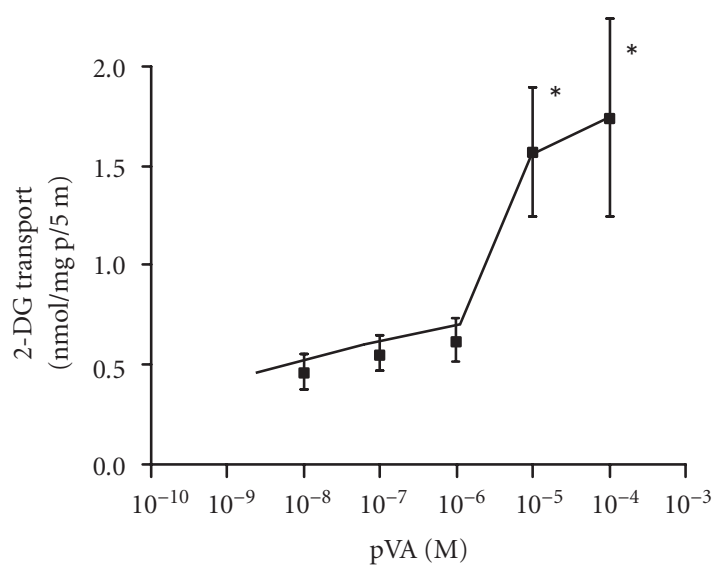

(a) Effect of pVA on 2-DG transport in 3T3 adipocytes.

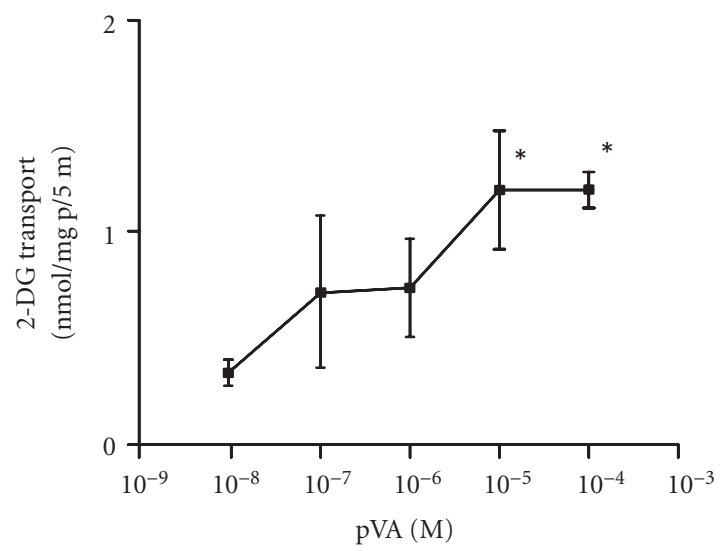

(b) Effect of pVI on 2-DG transport in 3T3 adipocytes.

Figure 3. Effect of different vanadate compounds at several concentrations on basal and insulin-stimulated 2-DG transport in 3T3-L1 adipocytes. Panel (a) pVA; ${ }^{*} P<.05$, 1-way ANOVA, $F=23.3, n=3$ (triplicate plates in all experiments). Panel (b) pVI; ${ }^{*} P<.05,1$-way ANOVA, $F=7.7, n=3$ (triplicate plates in all experiments). All data \pm SE. pVA or pVI exposure time was 60 minutes. See Materials and Methods for additional experimental details.

orthovanadate $\left(10^{-8} 10^{-4} \mathrm{~mol} / \mathrm{L}\right)$ (Figure 6$)(P<.05, n=3$, 1 -way ANOVA). Further, the myotubes exhibited increases in 2-DG transport only at a concentration of $10^{-4} \mathrm{~mol} / \mathrm{L} \mathrm{pVA}$ or pVI (Figure 6) $(P<.05, n=3,1$-way ANOVA). The observed increases were $153 \%$ for $\mathrm{pVA}$, and $166 \%$ for $\mathrm{pVI}$, these compared favorably with the increase seen in $67 \mathrm{nmol} / \mathrm{L}$ insulin (eg, 160\%, data not shown). Combinations of any of the vanadates tested with $67 \mathrm{nmol} / \mathrm{L}$ insulin did not result in any change in 2-DG transport as seen with either treatment (data not shown).

\section{DISCUSSION}

We have done an extensive study in a number of cell lines characterizing the effects of a variety of vanadates on 


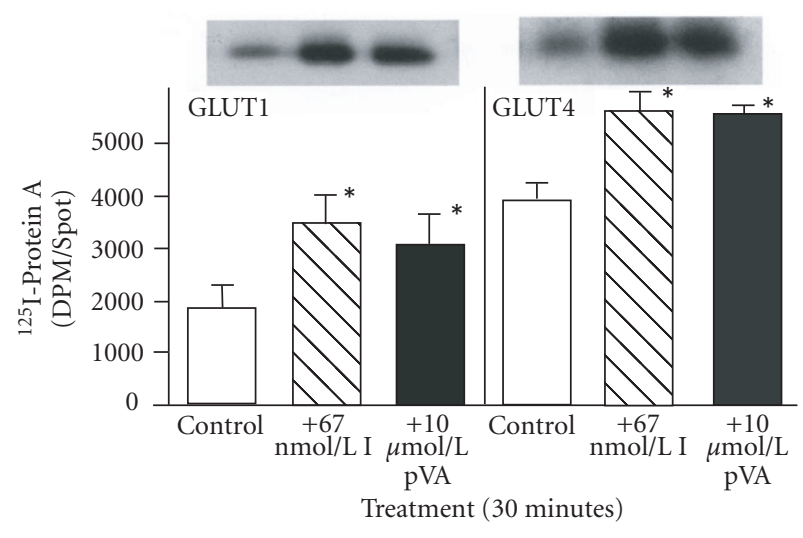

FIgURE 4. Effect of insulin and pVA on GLUT1 and GLUT4 transporter translocation in 3T3-L1 adipocytes. The GLUT1 and 4 transporters content are expressed in crude plasma membrane preparations in control, insulintreated (ie, $67 \mathrm{nmol} / \mathrm{L} \mathrm{I}$ ) and pVA treated (ie, $10^{-5} \mathrm{~mol} / \mathrm{L} \mathrm{pVA}$ ) membranes. GLUT $1:{ }^{*} P<.05$; 1 -way ANOVA, $F=6.8$, GLUT4: ${ }^{*} P<.05$, 1 -way ANOVA, $F=7.7, n=3$. All data \pm SE.

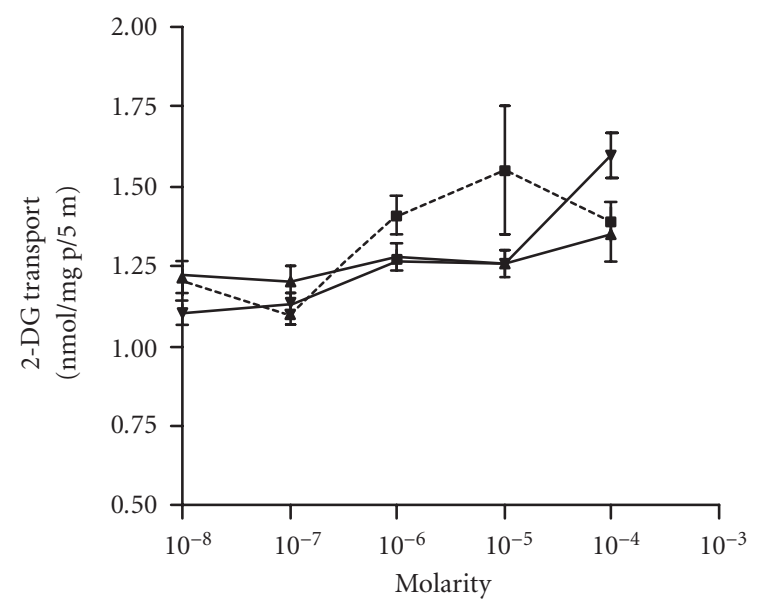

FIGURE 5. Effect of different vanadate compounds on 2-DG transport in L6 myoblasts. Sodium orthovanadate ( - - - $\mathbf{\square})$, no significant differences were seen. $P>.05,1$-way ANOVA, $F=1.33, n=8$ (triplicate plates in all experiments). pVA $(\boldsymbol{\Lambda}-\mathbf{\Lambda}),{ }^{*} P<.05,1$-way ANOVA, $F=6.43, n=6$ (triplicate plates in all experiments). pVI $(\mathbf{\nabla}-\mathbf{\nabla}),{ }^{*} P<.05,1$-way ANOVA, $F=13.0$, $n=6$ (triplicate plates in all experiments). All data \pm SE. The exposure time for all vanadate compounds was 60 minutes. See Materials and Methods for additional experimental details.

basal and insulin-stimulated 2-DG transport. Clearly, two patterns of effect have been seen: (1) sodium orthovanadate was not effective in stimulating basal 2-DG transport in the cell lines tested and (2) pervanadates were effective in all cell lines at $10^{-5}$ to $10^{-4} \mathrm{~mol} / \mathrm{L}$ concentrations. This is similar to observations made in $[12,13]$. In all of the preceding data, the increases seen in 2-DG transport at maximally effective concentrations of different vanadates were comparable to insulin-stimulated 2-DG transport, alone or in combination with a respective vanadate.

The L6 and 3T3-L1 cells were induced to differentiate into their respective insulin target (ie, the myotube and adipocyte). Dramatic increases were seen in GLUT1 and

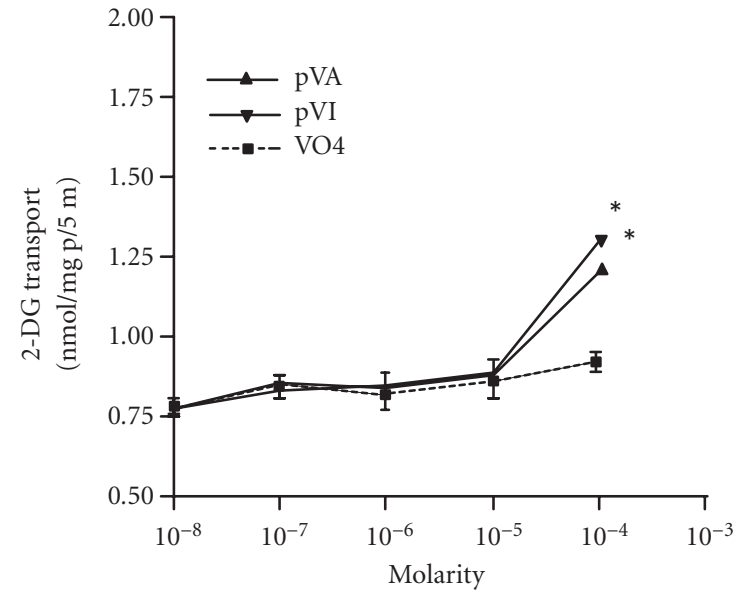

FIGURE 6. Effect of different vanadate compounds on 2-DG transport in L6 myotubes. Sodium orthovanadate $(\mathbf{\square}-\mathbf{-})$ : no significant differences were seen, $P>.05$, 1-way ANOVA, $F=0.84, n=3$ (triplicate plates in all experiments). pVA $(\boldsymbol{\Delta}-\mathbf{\Lambda}):{ }^{*} P<.05$, 1-way ANOVA, $F=7.3, n=3$ (triplicate plates in all experiments). pVI $(\boldsymbol{\nabla}-\mathbf{\nabla}):{ }^{*} P<.05,1$-way ANOVA, $F=19.8$, $n=3$ (triplicate plates in all experiments). All data \pm SE. The exposure time for all vanadate compounds employed was 60 minutes. See Materials and Methods for additional experimental details.

GLUT4 transporter content during 3T3-L1 adipocyte induction $[29,30,31]$. Additionally, increased sensitivity to insulin was observed in 3T3-L1 adipocytes with insulin (ie, $67 \mathrm{nmol} / \mathrm{L}$ ) to control transport ratios of 4 -fold when compared to the average 1.3 to 1.5 -fold increases seen with $667 \mathrm{nmol} / \mathrm{L}$ insulin in 3T3-L1 fibroblasts. Also, we observed an increased content of GLUT1 and GLUT4 in the crude plasma membrane fraction (ie, transporter translocation) of 3T3-L1 adipocytes post exposure to insulin $(67 \mathrm{nmol} / \mathrm{L})$ or pVA $\left(10^{-5} \mathrm{~mol} / \mathrm{L}\right)$ (Figure 4$)$. Further, our laboratory [25] and others $[6,18]$ have shown that GLUT1, 3, and 4 transporters in L6 myotubes are translocated to the plasma membrane in response to insulin. The responses seen postexposure to pVA or pVI are at least 10-fold less effective in myotubes than adipocytes. Additionally, the myotubes do not respond to concentrations of orthovanadate up to $10^{-4} \mathrm{~mol} / \mathrm{L}$. We have not employed concentrations above $10^{-4} \mathrm{~mol} / \mathrm{L}$ orthovanadate as considerable toxicity to the cells has been reported $[15,32,33,34,35]$ and was observed (data not shown). What is intriguing is that the insulin/control 2-DG transport ratios observed, were similar to the insulin/control 2-DG transport ratios no matter which vanadate was employed. It is interesting that similar concentrations of different vanadate compounds are all maximally efficacious on 2-DG transport within an order of magnitude (eg, $10^{-5}$ to $10^{-4} \mathrm{~mol} / \mathrm{L}$ ). In other studies employing rat adipocytes, investigators have seen marginal effects of orthovanadate at $10^{-3} \mathrm{~mol} / \mathrm{L}$ on insulin receptor $\beta$ chain tyrosine kinase activity [28]. This concentration exhibited a greater response at similar concentrations with pervanadate (ie, more than 20 -fold increase in insulin receptor $\beta$ chain tyrosine kinase activity). In human fibroblasts, pervanadate exposure leads to a nearly 2-fold increase in basal 2-DG 
transport at a concentration of $10^{-5} \mathrm{~mol} / \mathrm{L}$ (insulin receptor $\beta$ chain tyrosine kinase activity in rat adipocytes at $10^{-5} \mathrm{~mol} / \mathrm{L}$ pervanadate resulted in more than 5 -fold increases in enzyme activity). In another study, the peak pervanadate effect on lipogenesis in rat adipocytes was observed at $10^{-5} \mathrm{~mol} / \mathrm{L}$ [16]. In the same study, the peak effect of this vanadate on protein synthesis was seen at $5 \times 10^{-8} \mathrm{~mol} / \mathrm{L}$ pervanadate, while for insulin this peak occurred at $5 \times 10^{-7} \mathrm{~mol} / \mathrm{L}$; and for orthovanadate, the peak stimulation was seen at $5 \times 10^{-5} \mathrm{~mol} / \mathrm{L}$ [16]. This indicated that the different biological responses will be affected by different vanadate compounds at different concentrations. In the initial studies employing stable peroxovanadium compounds [17], maximal effects of pVA and pVI on lipogenesis in rat adipocytes were found at $10^{-6} \mathrm{~mol} / \mathrm{L}$ and $10^{-4} \mathrm{~mol} / \mathrm{L}$, respectively. The preceding results are in general agreement with our findings on the concentration effects of different vanadates on 2-DG transport in a number of cell lines. The effects on protein synthesis exhibit greater sensitivity to pervanadate than we have seen with human fibroblasts. This is not surprising as this response requires a longer exposure period to observe an effect. With different vanadates, there may be multiple secondary effects occurring that are beyond our current state of knowledge.

Our results on 2-DG transport with the L6 myotubes indicated that the peak concentration found for the effect of pervanadate on $2-\mathrm{DG}$ transport was $10^{-5} \mathrm{~mol} / \mathrm{L}$. This is similar to our results for pervanadate seen in human fibroblasts, and for pVA in L6 myoblasts. Other investigators have shown an effect of orthovanadate on 2-DG transport but the concentration employed at peak effect was $10^{-2} \mathrm{~mol} / \mathrm{L}$ [36]. As our studies, did not exhibit an effect of orthovanadate, employed no concentration more than $10^{-4} \mathrm{~mol} / \mathrm{L}$ orthovanadate, we may have seen an effect at higher concentrations of orthovanadate. We do feel that the use of $10^{-2} \mathrm{~mol} / \mathrm{L}$ orthovanadate is unacceptable primarily regarding secondary nonspecific events due to reasons cited earlier in this text.

The studies reported herein are the most extensive examination of the effects of various vanadate compounds and different cell types reported to date. Our data show considerable agreement with vanadate effects on lipogenesis, insulin receptor tyrosine kinase, and 2-DG transport regarding the peak effective concentrations and comparisons with insulin and vanadate treated transport ratios in a variety of cultured cells, rat adipocytes, and skeletal muscle cells $[5,6,16,17,18,36]$. Additionally, higher concentrations of pVA and pVI were expected to show effects on 2-DG transport in 3T3-L1 adipocytes and L6 myotubes. A similar phenomenon was observed by others $[5,37,38,39]$ using orthovanadate and pervanadate to stimulate the biologic effects of insulin in adipocytes and skeletal muscle.

The effects of a wide spectrum of different vanadates on 2-DG transport in multiple cell lines exhibited similar responses in transport increases, whether the 2-DG transport was increased by 1 -fold or 4 -fold. Also, this was true for insulin-treated cells and for insulin plus pervanadate or peroxovanadate-treated cells but not for orthovanadate exposed cells. The suggestion is that the mechanism(s) involved are similar. As to the mechanism(s) involved, it is generally agreed that the different vanadates act via protein tyrosine phosphatase inhibition $[17,38]$ and not solely by the insulin receptor [13]. Additionally, some investigators have proposed that orthovanadate and pervanadate act in subtly different ways: the former as a competitive inhibitor of protein tyrosine phosphatases and the latter as a completely irreversible oxidizer of the catalytic cysteine residues of protein tyrosine phosphatase 1B [39]. This mechanism cannot exclude effects on other tyrosine kinases such as the nonreceptor tyrosine kinases (eg, CytPTK) [40]. Additionally, membraneous nonreceptor protein tyrosine kinases are activated by vanadates [41]. The preceding however, may have some bearing on the results obtained herein. Sodium orthovanadate has demonstrated no effective ability to stimulate sugar transport at $10^{-4} \mathrm{~mol} / \mathrm{L}$ or lower concentrations. Thus, its insulin mimetic ability is considerably limited when looking at sugar transport stimulation. This is readily differentiated from the insulin mimetic effects seen with the pervanadates, which are more effective stimulators of sugar transport (at least 2-3 orders of magnitude when considering $10^{-2} \mathrm{~mol} / \mathrm{L}$ as the reported effective concentration $[5,6,36]$ of vanadate on sugar transport). The pervanadates behave similar to insulin itself. Thus, it can be argued that the pervanadates are true insulin mimetics via the mechanism cited above [39], unlike orthovanadate which is considerably less effective in modulating sugar transport.

Finally, considerable effort has been directed at the potential of these compounds in the treatment for diabetes. The data reported herein indicate problems that have been cited and still must be addressed. These include (1) vanadium toxicity, (2) the effects on noninsulin responsive tissues (eg, HF), (3) the longterm effects on other tissues, and (4) compounds effective at lower concentrations. The solution to these problems should lead to the therapeutic use of modified vanadate compounds (ie, peroxovanadates) alone or in conjunction with insulin as an adjunct to diabetes therapy.

\section{REFERENCES}

[1] Underwood EJ. Trace Elements in Human and Animal Nutrition. 4th ed. New York, NY: Academic Press; 1977.

[2] Golden MH, Golden BE. Trace elements, potential importance in human nutrition with particular reference to zinc and vanadium. Br Med Bull. 1981;37:31-36.

[3] Tolman EL, Barris E, Burns M, Pansini A, Partridge R. Effects of vanadium on glucose metabolism in vitro. Life Sci. 1979;25:1159-1164.

[4] Clark AS, Fagan JM, Mitch WE. Selectivity of the insulin-like actions of vanadate on glucose and protein metabolism in skeletal muscle. Biochem J. 1985;232:273-276.

[5] Kadota S, Fantus IG, Deragon G, Guyda HJ, Posner BI. Stimulation of insulin-like growth factor II receptor binding and insulin receptor kinase activity in rat adipocytes. Effects of vanadate and $\mathrm{H}_{2} \mathrm{O}_{2}$. J Biol Chem. 1987;262:8252-8256. 
[6] Tsiani E, Bogdanovic E, Sorisky A, Nagy L, Fantus IG. Tyrosine phosphatase inhibitors, vanadate and pervanadate, stimulate glucose transport and GLUT translocation in muscle cells by a mechanism independent of phosphatidylinositol 3-kinase and protein kinase C. Diabetes. 1998;47:1676-1686.

[7] Brichard SM, Okitolonda W, Henquin JC. Long term improvement of glucose homeostasis by vanadate treatment in diabetic rats. Endocrinology. 1988;123:20482053.

[8] Blondel O, Bailbe D, Portha B. In vivo insulin resistance in streptozotocin-diabetic rats-evidence for reversal following oral vanadate treatment. Diabetologia. 1989;32:185-190.

[9] Cantley LC, Josephson L, Warner R, Yanagisawa M, Lechene C, Guidotti G. Vanadate is a potent $(\mathrm{Na}, \mathrm{K})$ ATPase inhibitor found in ATP derived from muscle. $J$ Biol Chem. 1977;252:7421-7423.

[10] Swarup G, Cohen S, Garbers DL. Inhibition of membrane phosphotyrosyl-protein phosphatase activity by vanadate. Biochem Biophys Res Commun. 1982;107:1104-1109.

[11] Swarup G, Speeg KV Jr, Cohen S, Garbers DL. Phosphotyrosyl-protein phosphatase of TCRC-2 cells. J Biol Chem. 1982;257:7298-7301.

[12] Sekar N, Li J, Shechter Y. Vanadium salts as insulin substitutes: mechanisms of action, a scientific and therapeutic tool in diabetes mellitus research. Crit Rev Biochem Mol Biol. 1996;31:339-359.

[13] Tsiani E, Fantus IG. Vanadium compounds: biological actions and potential as pharmacological agents. Trends Endocrinol Metab. 1997;8:51-58.

[14] Heyliger CE, Tahiliani AG, McNeill JH. Effect of vanadate on elevated blood glucose and depressed cardiac performance of diabetic rats. Science. 1985;227:14741477.

[15] Meyerovitch J, Farfel Z, Sack J, Shechter Y. Oral administration of vanadate normalizes blood glucose levels in streptozotocin-treated rats. J Biol Chem. 1987;262:6658-6662.

[16] Fantus IG, Kadota S, Deragon G, Foster B, Posner BI. Pervanadate [peroxide(s) of vanadate] mimics insulin action in rat adipocytes via activation of the insulin receptor tyrosine kinase. Biochemistry. 1989;28:88648871.

[17] Posner BI, Faure R, Burgess JW, et al. Peroxovanadium compounds: a new class of potent phosphotyrosine phosphatase inhibitors which are insulin mimetics. J Biol Chem. 1994;269:4596-4604.

[18] Tsakiridis T, Vranic M, Klip A. Disassembly of the actin network inhibits insulin-dependent stimulation of glucose transport and prevents recruitment of glucose transporters to the plasma membrane. J Biol Chem. 1994;269:29934-29942.

[19] Frost SC, Lane MD. Evidence for the involvement of vicinal sulfhydryl groups in insulin-activated hexose transport by 3T3-L1 adipocytes. J Biol Chem. 1985;260:2646-2652.
[20] Germinario RJ, Oliveira M, Leung H. Saturable and nonsaturable hexose uptake in cultured human skin fibroblasts. Can J Biochem. 1978;56:80-88.

[21] Germinario RJ, McQuillan A, Oliveira M, Manuel S. Enhanced insulin stimulation of sugar transport and DNA synthesis by glucocorticoids in cultured human skin fibroblasts. Arch Biochem Biophys. 1983;226:498505.

[22] Lowry OH, Roseborough NJ, Farr NJ, Randall RJ. Protein measurements with the Folin phenol reagent. J Biol Chem. 1955;193:265-275.

[23] Germinario RJ, Lakshmi TM, Thirion JP. Kinetic characteristics and regulation of hexose transport in a galactokinase-negative Chinese hamster fibroblast cell line: a good model for studies on sugar transport in cultured mammalian cells. J Cell Physiol. 1989;138:300304.

[24] Pratt SE, Colby-Germinario SP, Manuel S, Germinario RJ. Evidence that modulation of glucose transporter intrinsic activity is the mechanism involved in the allosemediated depression of hexose transport in mammalian cells. J Cell Physiol. 1994;161:580-588.

[25] Tao Y, Cianflone K, Sniderman AD, Colby-Germinario SP, Germinario RJ. Acylation stimulating protein (ASP) regulates sugar transport in the rat L6 muscle cell line. Biochem Biophys Acta. 1997;1344:221-229.

[26] Germinario RJ, Manuel S, Chang Z, Leckett B. Inhibitors of protein synthesis cause increased hexose transport in cultured human fibroblasts by a mechanism other than transporter translocation. J Cell Physiol. 1992;151:156-163.

[27] Baldwin SA, Baldwin JM, Lienhard GE. Monosaccharide transporter of the human erythrocyte. Characterization of an improved preparation. Biochemistry. 1982;21:3836-3842.

[28] Kadota S, Fantus IG, Deragon G, Guyda HJ, Hersh B, Posner BI. Peroxide(s) of vanadium: a novel and potent insulin-mimetic agent which activates the insulin receptor kinase. Biochem Biophys Res Commun. 1987;147:259-266.

[29] Gould GW, Derechin V, James DE, et al. Insulinstimulated translocation of the HepG2/erythrocytetype glucose transporter expressed in 3T3-L1 adipocytes. J Biol Chem. 1989;264:2180-2184.

[30] Thurmond DC, Ceresa BP, Okada S, Elmendorf JS, Coker K, Pessin JE. Regulation of insulinstimulated GLUT4 translocation by Munc18c in 3T3 L1 adipocytes. J Biol Chem. 1998;273:33876-33883.

[31] Charron MJ, Katz EB, Olson AL. GLUT4 gene regulation and manipulation. J Biol Chem. 1999;274:32533256.

[32] Roshchin AV, Ordzhonikidze EK, Shalganova IV. Vanadium-toxicity, metabolism, carrier state. J Hyg Epidemiol Microbiol Immunol. 1980;24:377-383.

[33] Domingo JL, Llobet JM, Tomas JM, Corbella J. Short term toxicity study of vanadium in rats. J Appl Toxicol. 1985;B5:418-421.

[34] Llobet JM, Domingo JL. Acute toxicity of vanadium 
compounds in rats and mice. Toxicol Lett. 1984;23:227231.

[35] Gil J, Miralpeix M, Carreras J, Bartrons R. Insulin-like effects of vanadate on glucokinase activity and fructose 2,6-bisphosphate levels in the liver of diabetic rats. J Biol Chem. 1988;263:1868-1871.

[36] Tsiani E, Abdullah N, Fantus IG. Insulin-mimetic agents vanadate and pervanadate stimulate glucose but inhibit amino acid uptake. Am J Physiol. 1997;272:C156-C162.

[37] Ewart HS, Klip A. Hormonal regulation of the $\mathrm{Na}(+)$ $\mathrm{K}(+)$-ATPase: mechanisms underlying rapid and sustained changes in pump activity. Am J Physiol. 1995;269:C295-C311.

[38] Foot E, Bliss T, Fernandes LC, Da Costa C, Leighton B. The effects of orthovanadate, vanadyl and peroxides of vanadate on glucose metabolism in skeletal muscle preparations in vitro. Mol Cell Biochem. 1992;109:157162.

[39] Shisheva A, Shechter Y. Mechanism of pervanadate stimulation and potentiation of insulin-activated glucose transport in rat adipocytes: dissociation from vanadate effect. Endocrinology. 1993;133:1562-1568.

[40] Huyer G, Liu S, Kelly J, et al. Mechanism of inhibition of protein-tyrosine phosphatases by vanadate and pervanadate. J Biol Chem. 1997;272:843-851.

[41] Elberg G, Li J, Leibovitch A, Shechter Y. Non-receptor cytosolic protein tyrosine kinases from various rat tissues. Biochim Biophys Acta. 1995;1269:299-306.

* Corresponding author.

E-mail: Ralph.germinario@staff.mcgill.ca

Fax: +1 514340 7502; Tel: +1 5143408260 ext 4336 

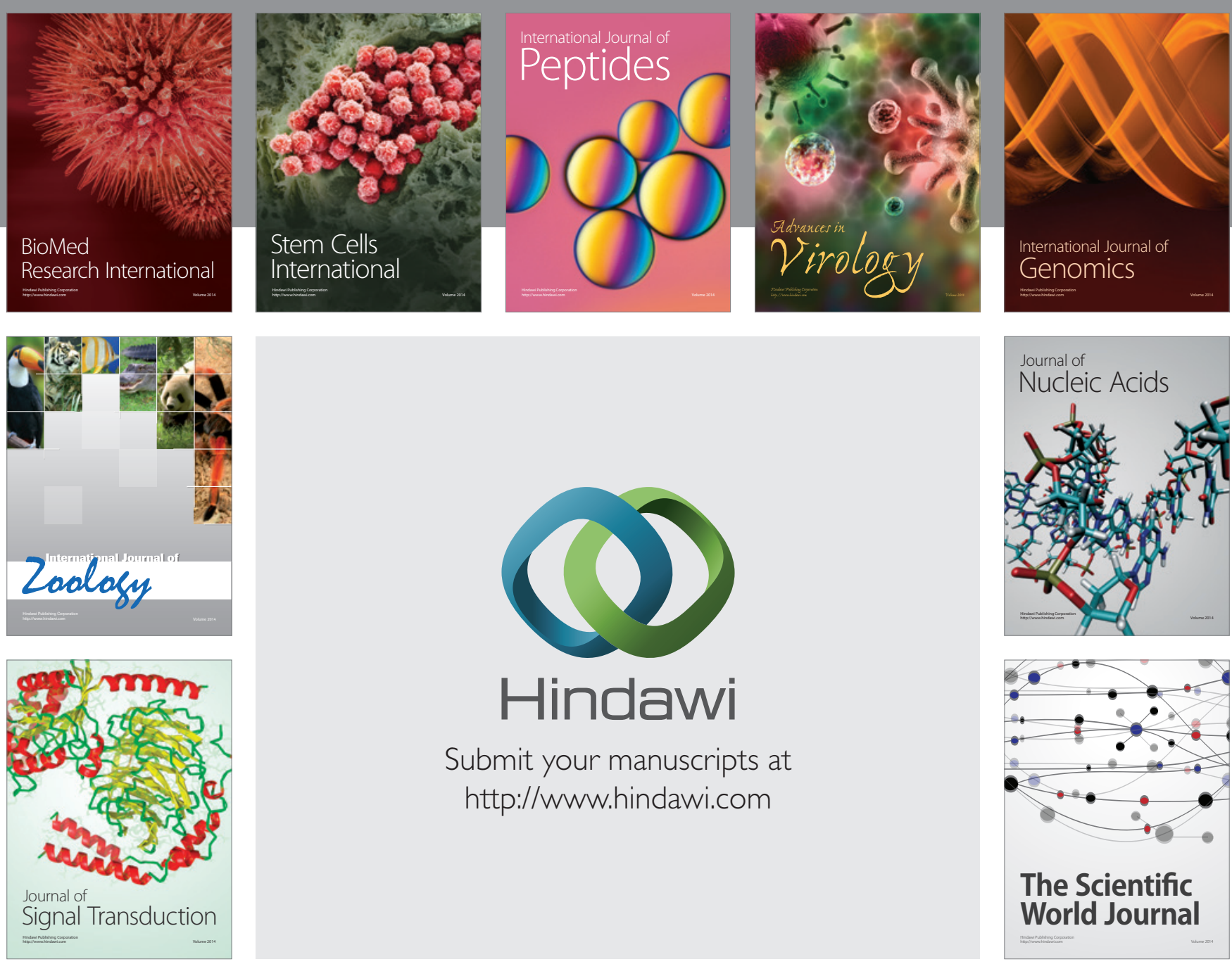

Submit your manuscripts at

http://www.hindawi.com
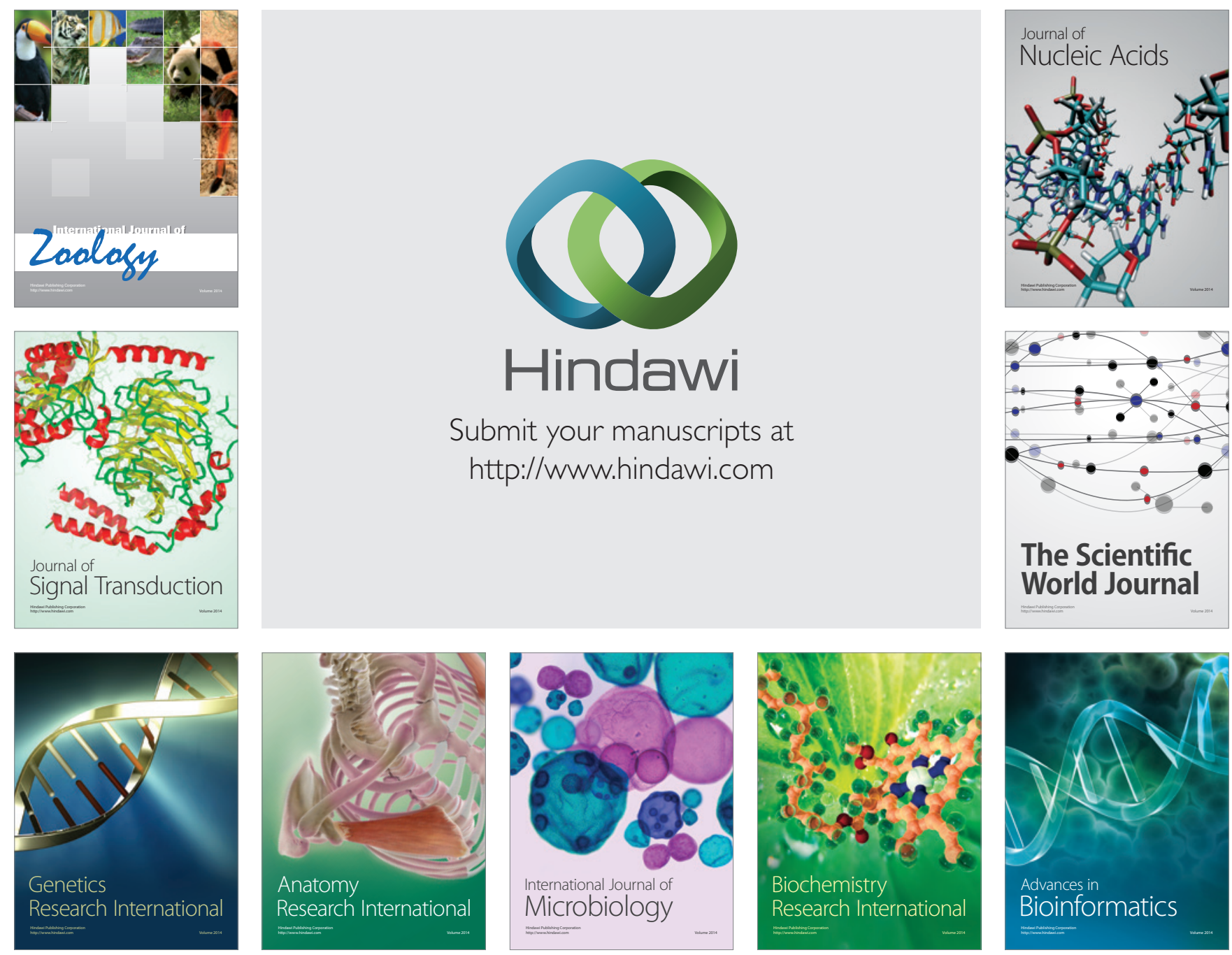

The Scientific World Journal
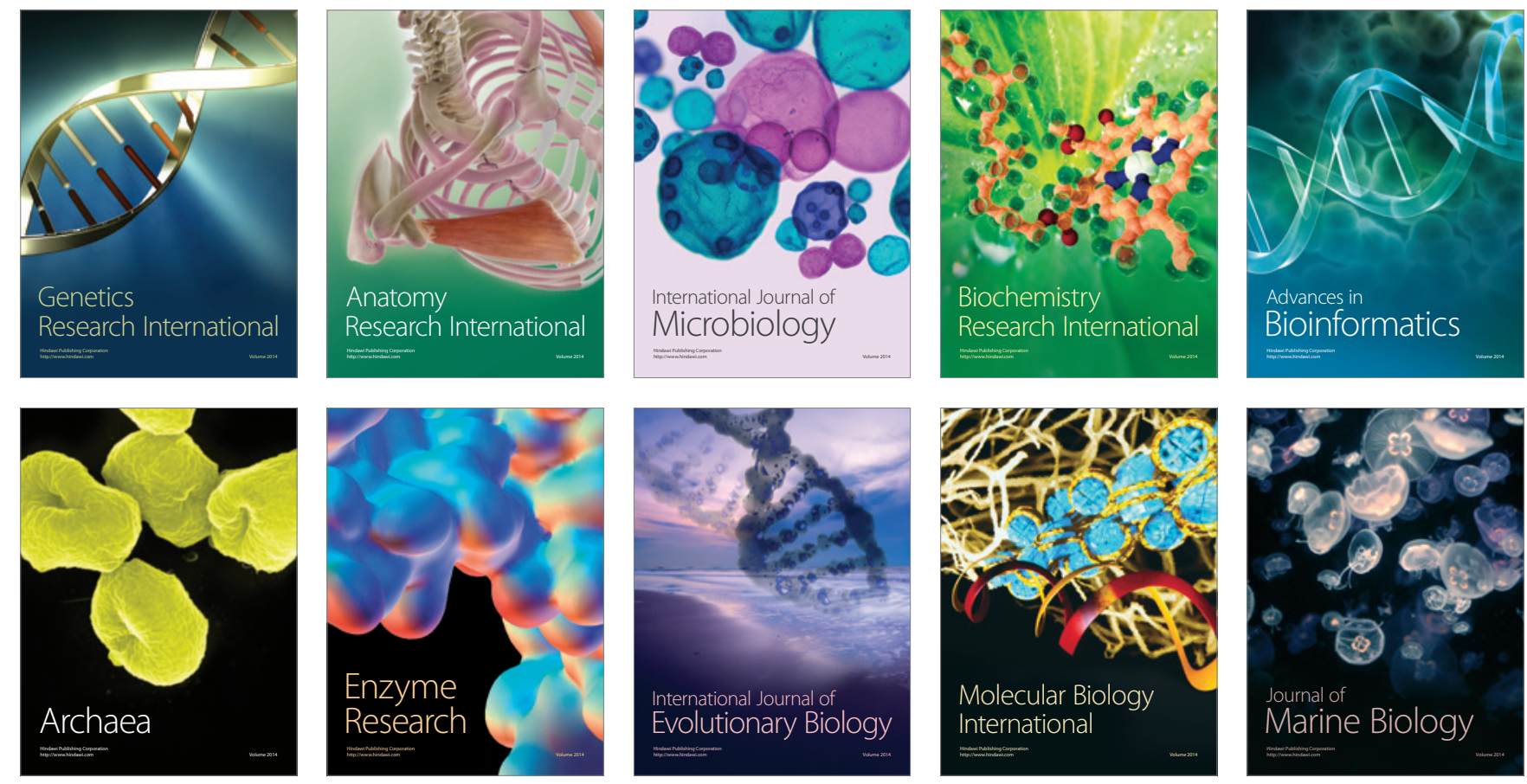